\title{
Evaluation of Neuropharmacological Activities of Methanolic and Aqueous Extracts of Citrus Reticulata (Rutaceae) Fruit Peels
}

\author{
Mohamed A Gbaj ${ }^{1}$, Inass A Sadawe ${ }^{1}$, Nisreen M Meiqal ${ }^{2}$, Salah M Bensaber ${ }^{2}$, Massaud Salem \\ Maamar $^{3}$, Anton Hermann ${ }^{4}$ and Abdul M Gbaj ${ }^{2 *}$ \\ ${ }^{1}$ Department of Chemical Engineering, University of Tripoli, Libya \\ ${ }^{2}$ Department of Medicinal Chemistry, University of Tripoli, Libya \\ ${ }^{3}$ Zoology Department, Faculty of Science, Tripoli University, Libya \\ 4Department of Biosciences, University of Salzburg, Austria
}

*Corresponding author: Abdul M Gbaj, Department of Medicinal Chemistry, Faculty of Pharmacy, University of Tripoli, Libya.

To Cite This Article: Abdul M Gbaj. Evaluation of Neuropharmacological Activities of Methanolic and Aqueous Extracts of Citrus Reticulata (Rutaceae) Fruit Peels. Am J Biomed Sci \& Res. 2019 - 2(4). AJBSR.MS.ID.000591. DOI: 10.34297/AJBSR.2019.02.000591

Received: March 09, 2019 | Published: April 17, 2019

\begin{abstract}
Introduction: Herbal medicines are getting more interest because of their cost-effective, eco-friendly attributes and proper reprieve from disease condition. The present study was designed to evaluate the anxiolytic activity potentials in peels of Citrus reticulata (Family: Rutaceae) in Libya.
\end{abstract}

Methods: The peel of the fruits were separated and subjected to cold extraction using 99\% Methanol and hot water extraction. The extracts obtained were screened for anxiolytic activity of extracts at 1.25 to $5 \mathrm{mg} / \mathrm{Kg}$ body weight concentrations and were assessed by Elevated Plus Maze.

Results: The results revealed that, both extracts treated animals have shown significant anxiolytic activity. From the results it was evident that citrus peel extract of Citrus reticulata exhibited significant anxiolytic activity.

Conclusion: From the results it was evident that Citrus reticulata has prominent activity in terms of parameters assessed in a dose dependent manner.

Keywords: Citrus reticulata; Anxiolytic activity; Psychopharmacology

\section{Introduction}

Human brain is a speculate in itself and is not explored entirely. It is a multifaceted gathering of interacting neurons and nuclei that control their own and each other's activities in a dynamic manner, usually throughout chemical neurotransmission. Psychopharmacology is the scientific learning of the effect's drugs encompass on mood, thinking, behavior and sensation. It is different from neuropsychopharmacology, which studies drug-induced alterations in the functioning of cells in the nervous system [1,2]. Two-thirds of the psychotic, depressed, or anxious patients react to the currently available treatments, but the enormity of improvement is not very significant.

The majority of the drugs for these conditions used these days have adverse side effects so the need for better-tolerated, newer and more efficacious treatments is enduring far above the ground $[3,4]$. The main use of sedative-hypnotic and anxiolytic drugs is to promote calmness (sedatives or anxiolytics) or to create sleep (hypnotics-sedative). Human are exposed to states of restlessness and emotional tension. Anxiety always accompanies many medical and surgical conditions, and it is frequently an indication of psychiatric illness. When the symptoms turn into insufferable or interfere with the treatment of the underlying disease, and if counseling is not enough, drug treatment can be used to help patients manage with their anxiety [5]. There are many medicines are used to treat many psychotherapy and pharmacotherapy illness such as benzodiazepines, azapirones, and antidepressants and others [6].

Citrus reticulata (Rutaceae) is commonly known as naringin or Sentra (orange). It is a small spiny tree with thick top of slim branches, extensively grown in Egypt, Tunisia and Libya [7]. Mandarin is a collection name for this class of orange with thin, loose peel. The name 'tangerine might be applied as an interchange name 
to the entire group, but in trade, it is usually limited to the types with red-orange skin. The fruit has aphrodisiac, laxative, tonic properties and astringent $[8,9]$. It is also used to alleviate vomiting $[10,11]$. The fruit peel controls the skin moisture, rough and softens hard skin and possess a cleaning effect on oily skin [12]. Chemical composition of the volatile oil of the fruit peels of this species has been reported [13-17]. The effects of the volatile oil of C. reticulata has been studied against Saccharomyces cerevisiae [18], pathogenic fungi, Penicilliums larvae, Schistosoma mansion, Aspergillus flavus, and other microorganisms [19-24]. The volatile oil of C. reticulata also demonstrates the anticancer activity [25-27]. The present paper describes the neuropharmacological Activities of methanolic and aqueous extracts of Citrus reticulata (Rutaceae) fruit peels of the essential oil of the fruit peel of $\mathrm{C}$. reticulata of Tripoli region.

\section{Materials and Methods}

\section{Collection of plant material and Preparation of aqueous extract}

The oranges were bought from a shop in Tripoli (February 2019). The Citrus reticulata was identified and authenticated by a botanist. Orange rinds were peeled off carefully with the help of a sharp razor blade. Each rind sample was cut into smaller pieces and $30 \mathrm{~g}$ mass of the sample was taken. The sample was initially rinsed with distilled water. The fresh peels $(30 \mathrm{~g})$ were added to $30 \mathrm{ml}$ hot distilled water. In addition, another $30 \mathrm{~g}$ of the fresh peels were macerated in cold 99\% methanol for three hours. After 3 hours of maceration at room temperature $\left(28^{\circ} \mathrm{C}\right)$, the mixture was then was filtered under vacuum and the filtrate was stored at $4^{\circ} \mathrm{C}$ and used to treat animals as needed [28].

\section{Experimental models}

Swiss albino mice of either sex weighing about 18-28g (2-2.6-month-old) used for experimental purpose. They were housed in polypropylene cages in the air-conditioned room with the temperature maintained at $25 \pm 2{ }^{\circ} \mathrm{C}$, and $12 \mathrm{~h}$ alternating light and dark cycles. The mice were provided with a nutritionally adequate diet and drinking water ad libitum throughout the study. Approval by the Animal Ethics Committee for the experimental procedures obtained.

\section{Acute toxicity study}

Acute toxicity was generally carried out for the determination of LD50 value in experimental animals. The aim of performing acute toxicity study is for establishing therapeutic index of a methanolic and aqueous extracts of Citrus reticulata and to ensure safety in-vivo. Acute toxicity test was performed in mice. All animals were fasted overnight before treatment and were given food one hour after aqueous and methanolic extracts. General behavior was also observed at $0.5,1,8,12$ and $24 \mathrm{~h}$ after administration. The number of animals that died after administration was traced daily for 7 days $[29,30]$.

\section{Elevated plus-maze test}

Elevated plus-maze is simple apparatus to study neuroprotective effects $[31,32]$ and anxiolytic responses produced by the test drugs. It is used to test almost all types of anxiolytic agents. Expo- sure of animals to novel maze alley suggests an approach-avoidance conflict which is stronger in open arm as compared to enclosed arm. Rodents (rats and mice) have an aversion for high and open space and prefer enclosed arm, consequently, spend a greater amount of time in enclosed arm. When animals enter open arm, they freeze, become immobile, defecate and show fear-like movements [33]. The cortisol plasma level is increased, as a true reflection of anxiety. Major advantages of this test procedure are:

a) It is less time consuming, simple and quick

b) no noxious stimuli (light or sound) or prior training is required, and

c) it is conventional and consistent procedure for studying anxiety response as well as anxiolytic action of drug [34,35].

Animals were weighed, numbered, and divided into five groups, each consisting 6 mice. One group was used as control (saline), second for standard drug (diazepam) treatment; groups 3-6 for aqueous Citrus reticulata extract treatment $(1.25,2.5,3.75,5.00 \mathrm{mg} / \mathrm{kg}$, intra-peritoneally) and groups 7-10 for methanolic Citrus reticulata extract treatment $(1.25,2.5,3.75,5.00 \mathrm{mg} / \mathrm{kg}$, intra-peritoneally). Animals were placed individually in the center of the maze, head facing toward open arm and stopwatch was started. The following parameters were noted for $5 \mathrm{~min}$.

i. First favorite of mouse to open or closed arm.

ii. Number of entries in open arm (an arm entry defined as the entry of four paws into the arm).

iii. Average time each animal spends in open arm (Average time $=$ total duration in the arm/number of entries) was estimated.

Saline and diazepam were injected to the control and standard groups respectively. Citrus reticulata extracts were injected to the test groups. After thirty minutes, animals were located individually in the center of the maze. Lastly, a comparison of the preference of the animals to open or enclosed arm, average time spent in open arm and the number of entries in open arm in each group were determined and recorded [36].

\section{Statistical Analysis}

Data were expressed by mean \pm standard error mean. For comparison among the groups, we used analysis of variance with multiple comparisons by post-hoc Dunnett t-test method. The statistical significance of differences between the control and experimental groups was assessed by Dunnett's two-sided t-tests (post-hoc tests). Statistical analysis was done using Statistical Package for the Social Sciences for windows (version 17.0, SPSS Inc., Chicago., USA). Statistical significance was considered $\mathrm{P}<0.05$ level.

\section{Result}

\section{Acute toxicity study}

With the growing amount of research about naringin as a component of the orange and its potential utilize within the pharmacological and food industries, illuminating its toxicological outline 
becomes increasingly significant. In the present study, the Citrus reticulata extracts were found to be safe up to $200 \mathrm{mg} / \mathrm{kg}$ orally. This

oral single dose of $16 \mathrm{~g} / \mathrm{kg}$ of naringin did not produce acute oral present study is compared with other previous studies in which an

\begin{tabular}{|c|c|c|c|c|c|c|}
\hline \multicolumn{7}{|c|}{ Mean \pm SEM } \\
\hline \multirow[t]{2}{*}{ Group } & \multicolumn{2}{|c|}{ Number of Entries in Open Arm } & \multicolumn{2}{|c|}{ Total Entries } & \multicolumn{2}{|c|}{$\begin{array}{l}\text { Percentage Ratio of Open/Total Arms } \\
\text { Entry }\end{array}$} \\
\hline & Aqueous Extract & Methanolic Extract & Aqueous Extract & Methanolic Extract & Aqueous Extract & Methanolic Extract \\
\hline Control & $7.02 \pm 0.23$ & $7.02 \pm 0.23$ & $33.20 \pm 1.02$ & $33.20 \pm 1.02$ & 21 & 21 \\
\hline Diazepam & $39.14 \pm 0.85$ & $39.14 \pm 0.85$ & $50.23 \pm 0.35$ & $50.23 \pm 0.35$ & 78 & 78 \\
\hline $\begin{array}{l}\text { Citrus reticulata } \\
1.25 \mathrm{mg} / \mathrm{kg}\end{array}$ & $20.03 \pm 2.01$ & $22.04 \pm 1.01$ & $40.2 \pm 0.23$ & $41.2 \pm 0.26$ & 50 & 53 \\
\hline $\begin{array}{l}\text { Citrus reticulata } \\
2.50 \mathrm{mg} / \mathrm{kg}\end{array}$ & $23.0 \pm 0.96$ & $24.0 \pm 1.02$ & $42.02 \pm 0.38$ & $43.05 \pm 0.38$ & 55 & 56 \\
\hline $\begin{array}{l}\text { Citrus reticulata } \\
3.75 \mathrm{mg} / \mathrm{kg}\end{array}$ & $28.5 \pm 0.35$ & $30.4 \pm 0.85$ & $44.02 \pm 1.23$ & $46.02 \pm 0.83$ & 65 & 66 \\
\hline $\begin{array}{l}\text { Citrus reticulata } \\
5.00 \mathrm{mg} / \mathrm{kg}\end{array}$ & $35.30 \pm 0.45$ & $36.30 \pm 1.01$ & $49.23 \pm 1.36$ & $50.33 \pm 1.26$ & 72 & 72 \\
\hline
\end{tabular}

\begin{tabular}{|c|c|c|c|c|}
\hline \multicolumn{5}{|c|}{ Mean \pm SEM } \\
\hline Group & $\begin{array}{l}\text { Time Spent in Open Arm } \\
\text { in Seconds }\end{array}$ & & $\begin{array}{l}\text { Time Spent in Close Arm } \\
\text { in Seconds }\end{array}$ & \\
\hline & Aqueous Extract & Methanolic Extract & Aqueous Extract & Methanolic Extract \\
\hline Control & $35.02 \pm 0.24$ & $35.02 \pm 0.24$ & $260.23 \pm 2.03$ & $260.23 \pm 2.03$ \\
\hline Diazepam & $130.04 \pm 1.23$ & $130.04 \pm 1.23$ & $160.23 \pm 2.34$ & $160.23 \pm 2.34$ \\
\hline Citrus reticulata $1.25 \mathrm{mg} / \mathrm{kg}$ & $85.03 \pm 1.23$ & $88.03 \pm 1.30$ & $230.0 \pm 1.35$ & $220.0 \pm 1.45$ \\
\hline Citrus reticulata $2.50 \mathrm{mg} / \mathrm{kg}$ & $92.0 \pm 0.95$ & $95.0 \pm 1.02$ & $204.32 \pm 1.11$ & $190.32 \pm 2.11$ \\
\hline Citrus reticulata $3.75 \mathrm{mg} / \mathrm{kg}$ & $98.5 \pm 1.02$ & $102.5 \pm 0.92$ & $175.32 \pm 2.35$ & $160.32 \pm 3.25$ \\
\hline Citrus reticulata $5.00 \mathrm{mg} / \mathrm{kg}$ & $106.30 \pm 1.45$ & $116.30 \pm 2.45$ & $140.23 \pm 2.35$ & $131.22 \pm 1.35$ \\
\hline
\end{tabular}

Tables $1 \& 2$ summarized the number of entries (open and total) of mice in elevated plus maze and the time spent by mice on elevated plus maze in open and closed arms, respectively.

\section{Discussion}

Recently, interests in powerful pharmacological properties and clinical applications of natural products for replacing synthetic drugs are rising. Despite of chief scientific and technological development in combinatorial chemistry, drugs obtained from natural products still create a huge contribution to drug discovery today. The citrus plant belongs to the family Rutaceae, comprising of about seventeen species found all over the tropical, subtropical and temperate regions [38,39]. Among the species, Citrus indica, Citrus ichangenesis Citrus latipes, Citrus megaloxycarpa, Citrus macroptera, Citrus jambhiri, Citrus aurantium, and Citrus reticulate are the most common. The genus citrus includes special essential fruits such as orange, mandarins, limes, lemons, and citrons grapefruits [38]. Even though, there are many groups of plants that are crucial in phytochemistry, citrus plantation has been assumed to be a valuable target for commercial agricultural and industrial practices in the world [40]. About 37 major components were identified from Citrus reticulata [41,42], and the major components were geranial (19.0\%), geranyl acetate (3.9\%), limonene (46.7\%), neral
(14.5\%), nerol (2.3), $\beta$-caryophyllene (2.6), citronellal (1.3\%), geraniol $(3.5 \%)$, and neryl acetate $(1.1 \%)$. Citrus oil also composed of aldehydes and esters being the lowest percentage components and about $97 \%$ monoterpenes with alcohols, with values ranging between 1.8 to $2.2 \%$ [43]. It has been reported that the identify of about 16-27 chemical constituents in the peel essential oil of C. reticulate was allocated including limonin and naringin and others [44-47].

Naringin is found in many plants. It is a flavonoid and was believed to relieve anxiety at the dose level below $3 \mathrm{mg} / \mathrm{kg}$ when given intra-peritoneally. At high doses it has been reported to cause sedation but no muscle relaxant property [48]. The anxiolytic effect of naringin has been studies using mice 6-8 weeks old and $30 \mathrm{~g}$ to $35 \mathrm{~g}$ weight and the anxiolytic effect was confirmed using elevated plus maze and locomotors activity and these results are in consistency with the results obtained in Table 1 \& 2 [48]. It has been reported that the diazepam 2 and $10 \mathrm{mg} / \mathrm{kg}$ dose were used which increased the number of open arm entries and percent of time spent in open arm as compared to saline control [48] and these results also are in consistency with the results obtained in Table $1 \& 2$.

The results obtained in Table $1 \& 2$ are also in agreements with studies done by Marder et al. $[49,50]$, which have shown that nar- 
ingin flavones (which is the main component of Citrus reticulata) at the level of dose 3 to $10 \mathrm{mg} / \mathrm{kg}$ to have excellent anxiolytic potential with no myorelaxation, sedation, or significant reduction in locomotor activity. It is reported that at high doses of narigine shows increase open arm exploration and decrease locomotor activity as shown from reduction in close arm eateries. Naringin and has anxiolytic and sedative potential at high doses. Naringin at dose $30 \mathrm{mg} /$ $\mathrm{kg}$ show a slight myorelaxant effect in the horizontal wire test [51]. It has been reported that naringin and its derivatives are mediators of GABA receptors and are supportive in relieving anxiety. This flavonoid also has some other targets such as Human Ether-a-go-goRelated Gene (hERG) voltage-dependent potassium channels and Inwardly Rectifying Potassium Channels (GIRK). This flavonoid has positive modulating effect on GIRK channels [52].

\section{Conclusion}

The present study demonstrated that the aqueous extract of peeled Citrus reticulata possess dose-dependent anxiolytic activity. Further, there is need to isolate, characterize, and screen the active principles that are responsible for its anxiolytic activity. Furthermore, there is need to find out the exact mechanism by which the Citrus reticulata extract exerts above effects. Further studies are needed to separate and confirm the active components and its effect on anxiety.

\section{Acknowledgement}

The authors gratefully acknowledge the technical support and valuable suggestions obtained from MS Amira Abdul Gbaj.

\section{Conflict of interest}

No Conflict of Interest.

\section{References}

1. Kornetsky C (1970) Psychoactive drugs in the immature organism. Psychopharmacologia 17(2): 105-136.

2. Eiduson S (1960) Brain and behavior: 1. Neurohumors, drugs, and behavior. Am J Orthopsychiatry 30: 1-9.

3. Wu Z, Cao L, Peng D, Mellor D, Zhang C, et al. (2018). The clinical correlates of comorbid anxiety symptoms and syndromal anxiety in patients with major depressive disorder. Psychiatry Res 269: 251-257.

4. Falk MA (1973) The computer analyzes two psychotherapeutic agents in anxiety-depressed states. Curr Ther Res Clin Exp 15(7): 488-499.

5. Lader M, Morton S (1991) Benzodiazepine problems. Br J Addict 86(7): 823-828.

6. Griffiths RR, Ator NA, Roache JD, Lamb RJ (1987) Abuse liability of triazolam: experimental measurements in animals and humans. Psychopharmacol Ser 3: 83-87.

7. Sharif SI, Ali BH (1994) Effect of grapefruit juice on drug metabolism in rats. Food Chem Toxicol 32(12): 1169-1171.

8. Tseng SH, Lee HH, Chen LG, Wu CH, Wang CC (2006) Effects of three purgative decoctions on inflammatory mediators. J Ethnopharmacol 105(1-2): 118-124.

9. Mc Guire RG, Hagenmaier RD (2001) Shellac formulations to reduce epiphytic survival of coliform bacteria on citrus fruit postharvest. J Food Prot 64(11): 1756-1760.

10. Yin OQ, Gallagher N, Li A, Zhou W, Harrell R, et al. (2010) Effect of grapefruit juice on the pharmacokinetics of nilotinib in healthy participants. J Clin Pharmacol 50(2): 188-194.
11. Glasscock SG, Friman PC, O Brien S, Christophersen ER (1986) Varied citrus treatment of ruminant gagging in a teenager with Batten's disease. J Behav Ther Exp Psychiatry 17(2): 129-133.

12. Khan MA, Ali M, Alam P (2010) Phytochemical investigation of the fruit peels of Citrus reticulata Blanco. Nat Prod Res 24(7): 610-620.

13. Fayek NM, Farag MA, Abdel Monem AR, Moussa MY, Abd-Elwahab SM, et al. (2019) Comparative Metabolite Profiling of Four Citrus Peel Cultivars via Ultra-Performance Liquid Chromatography Coupled with Quadrupole-Time-of-Flight-Mass Spectrometry and Multivariate Data Analyses. J Chromatogr 57(4): 349-360.

14. Guo Q, Liu K, Deng W, Zhong B, Yang W, et al. (2018) Chemical composition and antimicrobial activity of Gannan navel orange (Citrus sinensis Osbeck cv. Newhall) peel essential oils. Food Sci Nutr 6(6): 1431-1437.

15. Xu C, Zhang S, Zhang Y, Pu Y, Yin L, et al. (2018) Determination of spirotetramat and its four metabolites in citrus by ultra-highperformance liquid chromatography-triple quadrupole-ion trap mass spectrometry. Se Pu 36(4): 339-344.

16. Kealey KS, Kinsella JE (1978) Orange juice quality with an emphasis on flavor components. CRC Crit Rev Food Sci Nutr 11(1): 1-40.

17. Dunlap WJ, Wender SH (1960) Purification and identification of flavanone glycosides in the peel of the sweet orange. Arch Biochem Biophys 87: 228-231.

18. Singh P, Shukla R, Kumar A, Prakash B, Singh S, et al. (2010) Effect of Citrus reticulata and Cymbopogon citratus essential oils on Aspergillus flavus growth and aflatoxin production on Asparagus racemosus. Mycopathologia 170(3): 195-202.

19. Lemes RS, Alves CCF, Estevam EBB, Santiago MB, Martins CHG, et al. (2018) Chemical composition and antibacterial activity of essential oils from Citrus aurantifolia leaves and fruit peel against oral pathogenic bacteria. An Acad Bras Cienc 90(2): 1285-1292.

20. Uckoo RM, Jayaprakasha GK, Vikram A, Patil BS (2015) Polymethoxyflavones Isolated from the Peel of Miaray Mandarin (Citrus miaray) Have Biofilm Inhibitory Activity in Vibrio harveyi. J Agric Food Chem 63(32): 7180-7189.

21. Mehmood B, Dar KK, Ali S, Awan UA, Nayyer AQ, et al. (2015) Short communication: in vitro assessment of antioxidant, antibacterial and phytochemical analysis of peel of Citrus sinensis. Pak J Pharm Sci 28(1): 231-239.

22. Mahadwar G, Chauhan KR, Bhagavathy GV, Murphy C, Smith AD, et al. (2015) Swarm motility of Salmonella enterica serovar Typhimurium is inhibited by compounds from fruit peel extracts. Lett Appl Microbiol 60(4): 334-340.

23. Rakholiya K, Kaneria M, Chanda S (2014) Inhibition of microbial pathogens using fruit and vegetable peel extracts. Int J Food Sci Nutr 65(6): 733-739.

24. Min KY, Kim HJ, Lee KA, Kim KT, Paik HD (2014) Antimicrobial activity of acid-hydrolyzed Citrus unshiu peel extract in milk. J Dairy Sci 97(4):1955-1960.

25. Nair SA, Sr RK, Nair AS, Baby S (2018) Citrus peels prevent cancer. Phytomedicine 50: 231-237.

26. Arora S, Mohanpuria P, Sidhu GS, Yadav IS, Kumari V (2018) Cloning and Characterization of Limonoid Glucosyltransferase from Kinnow Mandarin (Citrus reticulata Blanco). Food Technol Biotechnol 56(2): 228-237.

27. Tahsin T, Wansi JD, Al Groshi A, Evans A, Nahar L, et al. (2017) Cytotoxic Properties of the Stem Bark of Citrus reticulata Blanco (Rutaceae). Phytother Res 31(8): 1215-1219.

28. Gray AM, Flatt PR (1999) Insulin-releasing and insulin-like activity of the traditional anti-diabetic plant Coriandrum sativum (coriander). $\mathrm{Br}$ J Nutr 81(3): 203-209. 
29. Ni H, Peng L, Gao X, Ji H, Ma J, et al. (2019) Effects of maduramicin on adult zebrafish (Danio rerio): Acute toxicity, tissue damage and oxidative stress. Ecotoxicol Environ Saf 168: 249-259.

30. Wheeler MW (2018) Bayesian additive adaptive basis tensor product models for modeling high dimensional surfaces: an application to highthroughput toxicity testing. Biometrics.

31. Sidorova YS, Petrov NA, Zorin SN, Sarkisyan VA, Mazo VK, et al. (2019) New functional food ingredient - lipid module, source of astaxantine and plasmalogenes. Vopr Pitan 88(1): 49-56.

32. Peris-Sampedro F, Mounib M, Schele E, Edvardsson CE, Stoltenborg I, et al. (2019) Impact of Free-Choice Diets High in Fat and Different Sugars on Metabolic Outcome and Anxiety-Like Behavior in Rats. Obesity (Silver Spring) 27(3): 409-419.

33. Pellow S, Chopin P, File SE, Briley M (1985) Validation of open: closed arm entries in an elevated plus-maze as a measure of anxiety in the rat. J Neurosci Methods 14(3): 149-167.

34. Gudasheva TA, Deeva OA, Mokrov GV, Dyabina AS, Yarkova MA, et al. (2018) Design, synthesis and anxiolytic activity evaluation of $\mathrm{N}$-acyltryptophanyl-containing dipeptides, potential TSPO ligands. Med Chem.

35. Fan J, Li D, Chen HS, Huang JG, Xu JF, et al. (2019) Metformin produces anxiolytic-like effects in rats by facilitating GABAA receptor trafficking to membrane. Br J Pharmacol 176(2): 297-316.

36. Hope BV, Hamilton TJ, Hurd PL (2019) Submerged plus maze: A novel test for studying anxiety-like behaviour in fish. Behav Brain Res 362: 332-337.

37. Li P, Wang S, Guan X, Cen X, Hu C, et al. (2014) Six months chronic toxicological evaluation of naringin in Sprague-Dawley rats. Food Chem Toxicol 66: 65-75.

38. Ulukus D, Tugay O (2018) Haplophyllumermenekense (Rutaceae), a new species from Turkey. PhytoKeys 111: 119-131.

39. Jatav S, Pandey N, Dwivedi P, Bansal R, Ahluwalia V, et al. (2018) Isolation of a new flavonoid and waste to wealth recovery of 6-0-Ascorbyl Esters from Seeds of Aegle marmelos (family- Rutaceae). Nat Prod Res 8: 1-7.

40. Yang J, Guo XM, Song YJ, Xiao SS, Niu DK (2012) Eco-hydrological characteristics and soil and water conservation effect of citrus plantation on slope red soil of Jiangxi Province, China. Ying Yong Sheng Tai Xue Bao 23(2): 468-474.

41. Anwar A, Masri A, Rao K, Rajendran K, Khan NA, etal. (2019) Antimicrobial activities of green synthesized gums-stabilized nanoparticles loaded with flavonoids. Sci Rep 9(1): 3122.
42. Gonzalez-Mas MC, Rambla JL, Lopez-Gresa MP, Blazquez MA, Granell A (2019) Volatile Compounds in Citrus Essential Oils: A Comprehensive Review. Front Plant Sci 10: 12.

43. Liu Z, Lindemeyer AK, Liang J, Wallner M, Shao XM, et al. (2018) Flavonoids isolated from Tibetan medicines, binding to GABAA receptor and the anticonvulsant activity. Phytomedicine 50: 1-7.

44. Khodabakhsh P, Shafaroodi H, Asgarpanah J (2015) Analgesic and anti-inflammatory activities of Citrus aurantium L. blossoms essential oil (neroli): involvement of the nitric oxide/cyclic-guanosine monophosphate pathway. J Nat Med 69(3): 324-331.

45. Salehi B, Fokou PVT, Sharifi-Rad M, Zucca P, Pezzani R, et al. (2019) The Therapeutic Potential of Naringenin: A Review of Clinical Trials. Pharmaceuticals (Basel) 12(1).

46. Sun Y, Tao W, Huang H, Ye X, Sun P (2019) Flavonoids, phenolic acids, carotenoids and antioxidant activity of fresh eating citrus fruits, using the coupled in vitro digestion and human intestinal HepG2 cells model. Food Chem 279: 321-327.

47. Khodayar MJ, Kalantari H, Mahdavinia M, Khorsandi L, Alboghobeish S, et al. (2018) Protective effect of naringin against BPA-induced cardiotoxicity through prevention of oxidative stress in male Wistar rats. Drug Chem Toxicol 1-11.

48. Fernandez SP, Nguyen M, Yow TT, Chu C, Johnston GA, et al. (2009) The flavonoid glycosides, myricitrin, gossypin and naringin exert anxiolytic action in mice. Neurochem Res 34(10): 1867-1875.

49. Liu Z, Lindemeyer AK, Liang J, Wallner M, Shao XM, et al. (2018) Flavonoids isolated from Tibetan medicines, binding to GABAA receptor and the anticonvulsant activity. Phytomedicine 50: 1-7.

50. Deeb 0, Shaik B, Agrawal VK (2014) Exploring QSARs of the interaction of flavonoids with GABA (A) receptor using MLR, ANN and SVM techniques. J Enzyme Inhib Med Chem 29(5): 670-676.

51. Fernandez SP, Nguyen M, Yow TT, Chu C, Johnston GA, et al. (2009) The flavonoid glycosides, myricitrin, gossypin and naringin exert anxiolytic action in mice. Neurochem Res 34(10): 1867-1875.

52.Zitron E, Scholz E, Owen RW, Luck S, Kiesecker C, et al. (2005) QTc prolongation by grapefruit juice and its potential pharmacological basis: HERG channel blockade by flavonoids. Circulation 111(7): 835-838. 